\title{
Notes on the Distribution and Natural History of the Eastern Wormsnake (Carphophis amoenus amoenus) in West Virginia
}

Eric H. Diefenbacher ${ }^{1}$ and Thomas K. Pauley ${ }^{2}$

${ }^{1}$ College of Science, Technology, \& Math, Alderson Broaddus University, Philippi, West Virginia 26412 (eric.diefenbacher@gmail.com) ${ }^{2}$ Department of Biological Sciences, Marshall University, Huntington, West Virginia 25755 (pauley@marshall.edu)

Photographs by the senior author.

Abstract.-Small fossorial snakes, such as the Eastern Wormsnake (Carphophis amoenus amoenus), are often neglected in studies since they lead a fossorial life and are frequently hard to find. Since it was last studied nearly 40 years ago, we present an update on distribution, habitat preferences, and diet of the Eastern Wormsnake in West Virginia. We found that this species resides in only a fraction of its original range due to habitat destruction by industrial, residential, and commercial developments. Habitat data suggests this species can tolerate a range of soil temperatures $\left(15-24^{\circ} \mathrm{C}\right)$, air temperatures $\left(23.1-34.3^{\circ} \mathrm{C}\right)$, and relative humidity $(24.5-80 \%)$, and can be found on nearly all slope directions. Dietary analysis showed annelids make up the majority of their diet but other invertebrate prey are also taken.

$\mathrm{T}$ he Eastern Wormsnake (Carphophis a. amoenus) is one of two subspecies of Common Wormsnakes found in West Virginia (the other being the Midwestern Wormsnake, C. a. helenae). Total body lengths are $20.3-45.7 \mathrm{~cm}$ in adults and $8-10 \mathrm{~cm}$ in juveniles. Eastern Wormsnakes have 13 rows of smooth dorsal scales, dorsal coloration that can range from dull brown to black, and ventral scales and the first two dorsal scale rows are typically pink (Fig. 1). The tail is short and tapers to a point; the cloacal plate is divided (Behler 2000).

Eastern Wormsnakes are fossorial, often found under rocks and logs and sometimes excavated during land development activity (Ernst and Ernst 2003). They predominantly reside in cool, moist soils next to unimpounded streams (Metts et al. 2001), hilly woodlands, pine forest stands (McLeod and Gates 1998), partially wooded or grassy hillsides next to streams, and farmland bordering woodlands from sea level to over 1,300 m (Behler 1991). Eastern Wormsnakes also have been found in dry upland forest more frequently than other fossorial snakes, suggesting that this species is very versatile in habitat choice (Willson and Dorcas 2004). Eastern Wormsnakes have home ranges of $23-726 \mathrm{~m}^{2}$ and exhibit no homing ability if displaced (Barbour et al. 1969).

Activity patterns suggest that the majority of movement occurs from April to October between midday and early evening (Barbour et al. 1969). Snakes retreat deep underground during hot summer months (Willison and Dorcas 2004) and

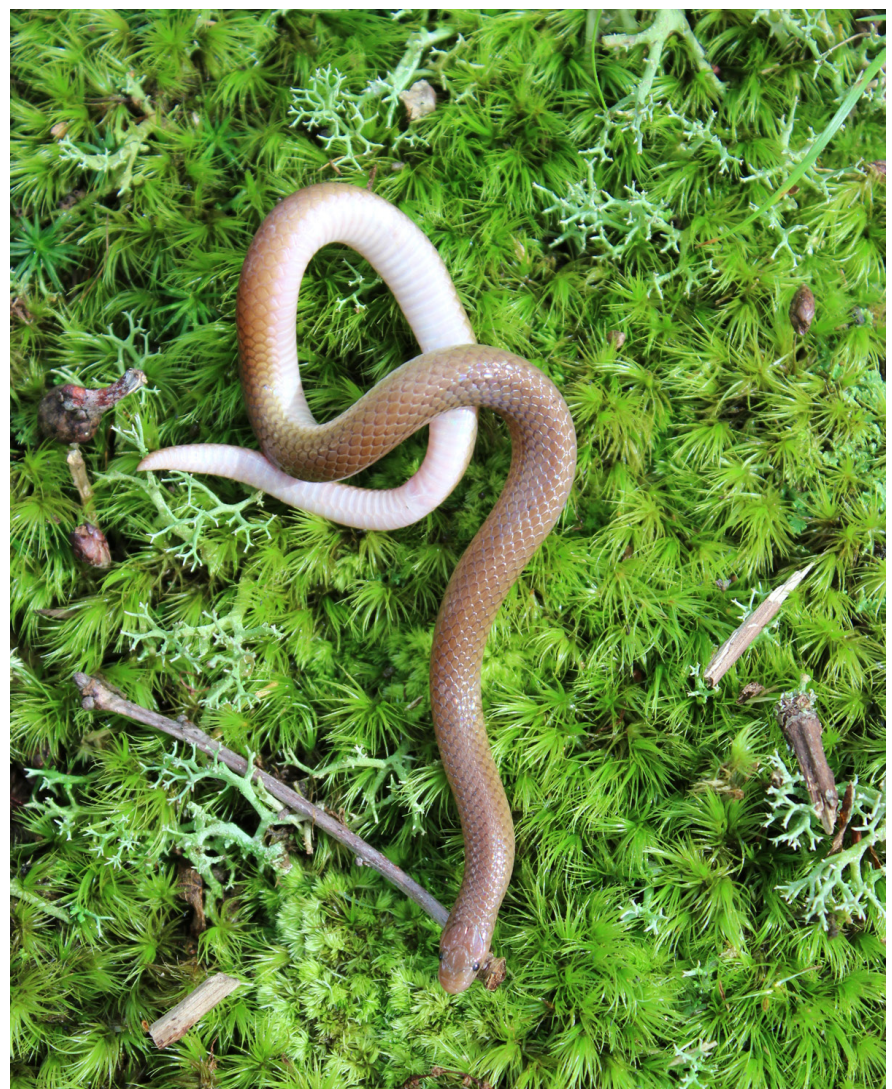

Fig. 1. The Eastern Wormsnake (Carphophis a. amoenus) is one of two subspecies of Common Wormsnakes found in West Virginia. 
emerge during cooler, moister months of spring and fall. This corresponds to breeding activity, which occurs during April to May and September to October. One to eight 23-mm elongated eggs are deposited from June to July and hatch in approximately seven weeks. Young mature within three years (Behler 1991). Eastern Wormsnakes do not display aggressive behavior when found, preferring to flee and burrow, but individuals might exhibit a coiled defensive posture with tail elevated to mimic the head (Diefenbacher and Pauley 2009). Feeding habits are widely unknown, but some studies suggest a diet mainly of earthworms (Hamilton and Pollack 1956, Ernst and Ernst 2003).

The total range of Eastern Worm Snakes extends from southern New England to central Georgia and west to central Alabama (Conant and Collins 1991). In West Virginia, records show no occurrences in Hancock, Brooke, Ohio, Marshall, Wetzel, Morgan, Jefferson, Tucker, Randolph, Preston, Upshur, Harrison, Monongalia, Tyler, Pleasants, Ritchie, and Jackson counties (Green and Pauley1987).

With the onset of global climate change and human expansion threatening biodiversity, monitoring populations of even lesser known organisms becomes increasingly important. Here we present a study on the distribution of Eastern Wormsnakes in West Virginia 40 years after these snakes were last studied by Pauley (1973), who found this genus to occur in 37 counties across the state. The main objective was to assess historical sites to determine if suitable habitat still exists; and, if so, do these snakes still reside at these sites. Because the diet of Eastern Wormsnakes is poorly known, a secondary objective was to examine the diet to provide a better understanding of the role played by these snakes in the leaf litter community.

\section{Methods}

We chose field sites based on historical records kept on file at the Marshall University Herpetological Museum in Huntington, West Virginia. We conducted diurnal visual encounter surveys for 1 hour at each site, April through
September, and turned all available cover objects. Upon detection, we collected snakes by hand and used Vernier calipers to measure snout-vent length (SVL), total body length (TBL), and tail length (TL); we determined sex by probing, recorded whether females were gravid or not, and counted dorsal scale rows and subcaudal scales. Environmental data included soil temperature using a soil thermometer placed no more than $2 \mathrm{~cm}$ into the soil, slope direction, habitat type, air temperature, relative humidity, type of cover object, and the maximum length, width, and depth of each cover object.

We performed dietary analyses using preserved specimens from the Marshall University Herpetological Museum. All available specimens had the contents of their gastrointestinal tracts removed and searched for identifiable anatomical parts of prey items. We recorded the same morphometric data as for field-collected snakes.

Results

We found snakes from April through August at soil temperatures of $15.0-24.0^{\circ} \mathrm{C}$, relative humidity of $24.5-80.0 \%$, and air temperatures of $23.1-34.3^{\circ} \mathrm{C}$ (Table 1). All were in mixed deciduous forest either on a hillside or top of a ridge under

Table 1. Environmental data recorded during field studies of Eastern Wormsnakes (Carphophis amoenus amoenus) in West Virginia. Means are presented \pm one standard deviation (SD).

\begin{tabular}{ll} 
Environmental Variable & Mean \pm one SD (range) \\
\hline $\mathrm{N}$ & 10 \\
\hline Soil temperature $\left({ }^{\circ} \mathrm{C}\right)$ & $19.1 \pm 3.2(15.0-24.0)$ \\
\hline Relative humidity $(\%)$ & $53.7 \pm 17.7(24.5-80.0)$ \\
\hline Air temperature $\left({ }^{\circ} \mathrm{C}\right)$ & $28.1 \pm 3.8(23.1-34.3)$ \\
\hline Cover object length $(\mathrm{cm})$ & $40.8 \pm 19.0(22.0-72.0)$ \\
\hline Cover object width $(\mathrm{cm})$ & $31.1 \pm 15.6(13.0-53.8)$ \\
\hline Cover object depth $(\mathrm{cm})$ & $7.0 \pm 6.1(0.5-19.0)$ \\
\hline
\end{tabular}
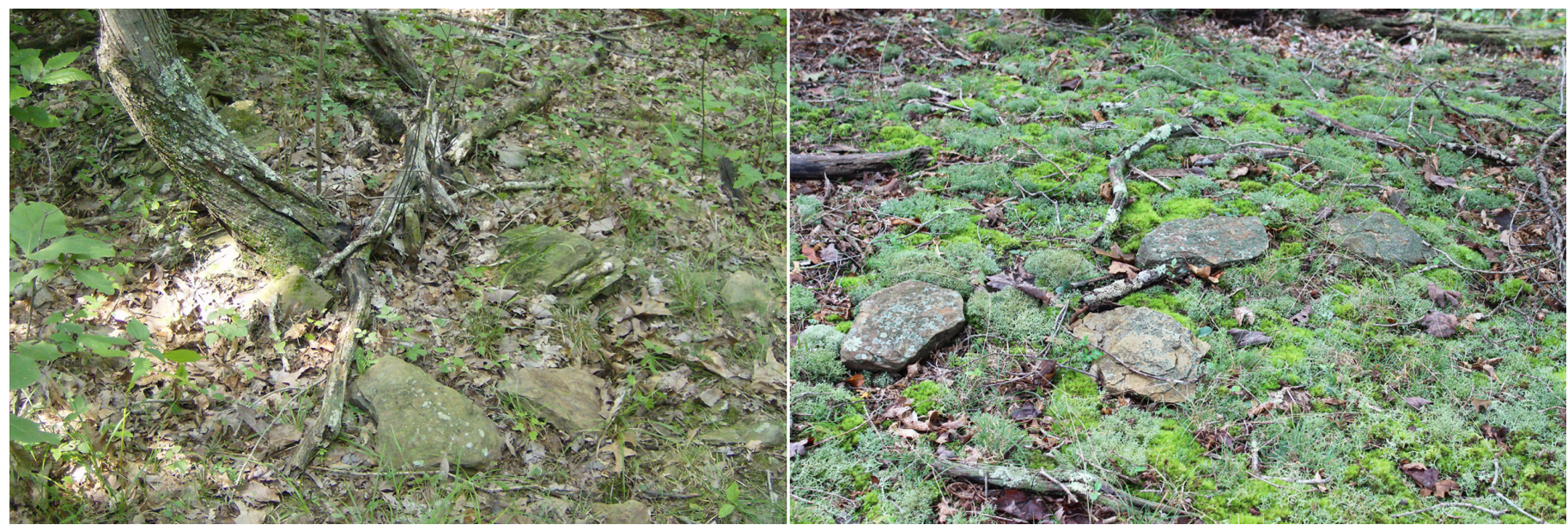

Fig. 2. Typical Eastern Wormsnake (Carphophis a. amoenus) habitat in West Virginia is characterized by small to large rocks that provide shelter for snakes. 
small to large flat rocks that rested on the substrate and were surrounded by moss and lichens (Figs. $2 \& 3$ ). We found snakes only in soil that promoted good vegetative growth; they were absent at sites with substrates consisting mainly of sand. Snakes were on all slope aspects; however, we found the most individuals on north- to northeast-facing slopes. Three gravid females with 3-6 eggs were present in June on west- or south-facing slopes.

Only three of the 37 historical sites and their corresponding counties contained habitat suitable for Eastern Wormsnakes. Sites with unsuitable habitat consisted mainly of residential, industrial, or commercial developments with open canopies, no cover objects, and large expanses of asphalt. All three of the historical sites where we found snakes were in state parks or forests.

We also found three individuals, two females and one male, of the Midwestern Wormsnake (Carphophis a. helenae), identified by the presence of fused prefrontal and internasal scales, at one site in Wayne County with the same habitat as that occupied by Eastern Wormsnakes.

Twenty-two of 78 specimens had contents in their gastrointestinal tracts. Contents that could be identified included setae from annelids, arachnid legs, coleopteran elytra, soil matter, and unidentifiable soft tissues.

Mean female SVL was greater than that of males, whereas males had longer tails and greater subcaudal scale counts than females ( $\mathrm{t}$-tests, $\mathrm{df}=77$, all $\mathrm{P}<0.05$; Table 2). Total body lengths did not differ significantly between males and females. Dorsal scale counts for both sexes were 13-13-13 for all individuals.

Table 2. Snout-vent lengths (SVL), total body lengths (TBL), tail lengths (TL), and subcaudal scale counts of Eastern Wormsnakes (Carphophis amoenus amoenus) in West Virginia. Means are presented \pm one standard deviation (SD).

\begin{tabular}{lll}
$\mathbf{N}$ & $\begin{array}{l}\text { Males } \\
\mathbf{4}\end{array}$ & $\begin{array}{l}\text { Females } \\
\mathbf{3 4}\end{array}$ \\
\hline SVL $(\mathbf{c m})$ & $7.3-21.2(17.0 \pm 3.3)$ & $8.1-24.6(19.1 \pm 3.2)$ \\
\hline TBL $(\mathbf{c m})$ & $9.1-26.7(20.7 \pm 4.1)$ & $9.1-28.8(22.2 \pm 3.7)$ \\
\hline TL $(\mathbf{c m})$ & $1.4-5.6(3.7 \pm 0.9)$ & $1.0-5.4(3.1 \pm 1.0)$ \\
\hline $\begin{array}{l}\text { Subcaudal } \\
\text { scale count }\end{array}$ & $15-42(33.4 \pm 4.3)$ & $13-34(25.9 \pm 3.9)$ \\
\hline
\end{tabular}
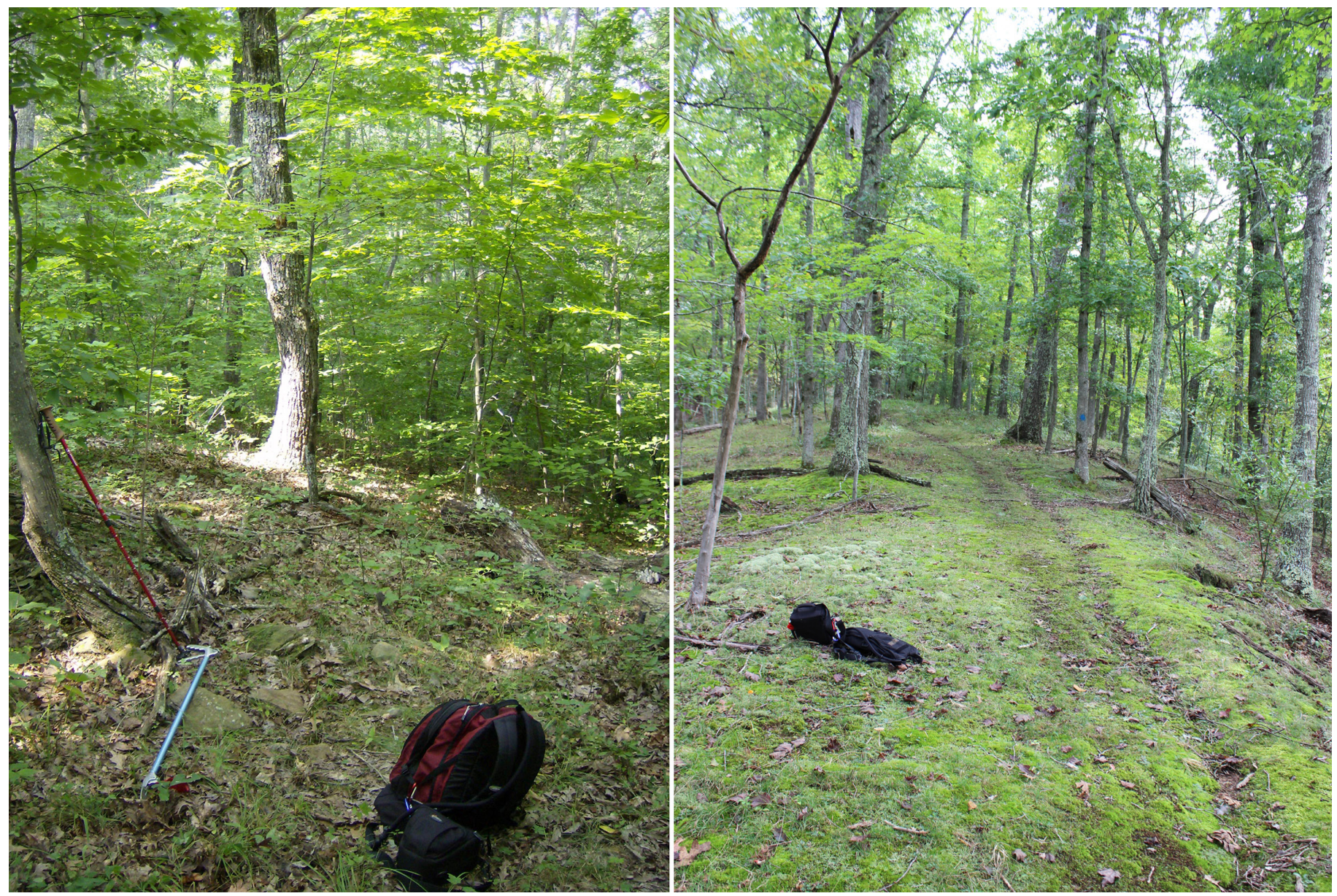

Fig. 3. Typical Eastern Wormsnake (Carphophis a. amoenus) habitat in West Virginia comprises mixed deciduous hillsides and ridges. 


\section{Discussion}

Because fossorial snakes are inherently difficult to study, we cannot say with any certainty if this species is in imminent danger of extirpation in the state of West Virginia. All sites where we failed to find Eastern Wormsnakes were destroyed or altered by housing developments, industrial complexes, and commercial developments. These areas had considerably more extensive asphalt substrates and open canopies than sites where we found snakes. These altered habitats generate more runoff and result in higher evaporation rates (Dodds and Whiles 2010). High volumes of runoff erode surrounding soil necessary for burrowing and high evaporation rates dry out the soil, potentially causing burrows to collapse. Because Wormsnakes require moist soils to remain hydrated (Ernst and Ernst 2003), the combined effects of warmer ground temperatures, impregnable substrates, and high evaporative water loss are likely to be contributing factors to the absence of snakes at these sites. Unfortunately, we have no records of what these historic sites looked like 40 years ago at the time of Pauley's (1973) study, so we were unable to make direct comparisons. The habitats where we most frequently found snakes were in moist soils under rocks of various sizes on hillsides and ridges. These observations are consistent with many other studies across the range of Eastern Wormsnakes (e.g., Ernst and Ernst 2003, Orr 2006).

We found gravid females during the hottest times of day (1200-1500 h) under smaller rocks and in rockier soils (relative to other individuals). Whether these observations reflect typical behavior of gravid females requires further research. Little is known about breeding and embryonic development (Ernst and Ernst 2003). Egg deposition in warmer areas might accelerate development so offspring hatch in time to exploit available prey before winter dormancy (Vitt and Caldwell 2009).

Dietary analyses indicate that annelids are the primary food source in West Virginia, but other invertebrate prey are also taken. Although we question the nutritional quality of a diet composed solely of annelids, Rossi and Rossi (1993) demonstrated that annelids are sufficiently nutritious to provide small snakes with an adequate diet. The discovery of coleopteran and arachnid prey adds to the list of known prey items that includes dipteran larvae (Uhler et al. 1939), slugs and snails (Wright and Wright 1957), and small salamanders (Clark 1970). Further research into the dietary habits of Wormsnakes should include stable isotope analysis. Tracing the paths of specific isotopes of carbon and nitrogen has already helped trace metabolic turnover in juvenile snakes (Fisk et al. 2009) and helped provide insights into trophic niches and how food resources are used between similar species in the same area (Willson et al. 2010). These same techniques could be applied to Wormsnakes and potential competitors, such as Ring-necked Snakes (Diadophis punctatus) and North American Brownsnakes (Storeria spp.) in the leaf litter community to facilitate a better understanding of these snake assemblages.

An important observation made during this study was the discovery of a population of Midwestern Wormsnakes (Carphophis a. helenae) at the same site as Eastern Wormsnakes in southwestern West Virginia. Although Midwestern Wormsnakes have been found in West Virginia (Pauley 1973), we found males and females of both subspecies within $200 \mathrm{~m}$ of one another at a single site. This reinforces the suggestion by Pauley (1973) that this site was in an intergradation zone. While genetic studies of Carphophis are lacking, this site does present itself as a source for future studies of interactions between these closely related forms.

\section{Acknowledgments}

We thank Valerie Diefenbacher, Scott Albaugh, Daniel Ware, Tim Baldwin, Reid Downer, Justin Weiss, and Kevin Saunders for their help during field surveys. This study was supported by the West Virginia Department of Natural Resources Wildlife Diversity Grant Program.

\section{Literature Cited}

Barbour, R.W., M.J. Harvey, and J.W. Hardin. 1969. Home range, movements, and activity of the Eastern Worm Snake, Carphophis amoenus amoenus. Ecology 50:470-476.

Behler, J.L. 1979. National Audubon Society Field Guide to Reptiles and Amphibians of North America. Alfred A. Knopf, New York.

Clark, D.R., Jr. 1970. Ecological study of the Worm Snake Carphophis vermis (Kennicott). University of Kansas Publications, Museum of Natural History 19:85-194.

Conant, R. and J.T. Collins. 1998. Reptiles \& Amphibians. Eastern and Central North America. 3rd ed., expanded. Houghton Mifflin Company, Boston, Massachusetts.

Diefenbacher, E.H. and T.K. Pauley. 2009. Carphophis amoenus helenae. Defensive Behavior. Herpetological Review 40:94-95.

Dodds, W. and M. Whiles. 2010. Freshwater Ecology: Concepts and Environmental Applications of Limnology. 2nd ed. Academic Press, Burlington, Massachusetts.

Ernst, C.H. and E.M. Ernst. 2003. Snakes of the United States and Canada. Smithsonian Books, Washington, D.C.

Fisk, A.T., K. Sash, J. Maerz, W. Palmer, J.P. Carroll, and M.A. MacNeil. 2009. Metabolic turnover rates of carbon and nitrogen stable isotopes in captive juvenile snakes. Rapid Communications in Mass Spectrometry 23:319-326.

Green, N.B. and T.K. Pauley. 1987. Amphibians and Reptiles in West Virginia. University of Pittsburgh Press, Pittsburgh, Pennsylvania.

Hamilton, W.J., Jr. and J.A. Pollack. 1956. The food of some colubrid snakes from Fort Benning, Georgia. Ecology 37:519-526.

McLeod, R.F. and J.E. Gates. 1998. Response of herpetofaunal communities to forest cutting and burning at Chesapeake Farms, Maryland. American Midland Naturalist 139:164-177.

Metts, B.S., J.D. Lanham, and K.R. Russell. 2001. Evaluation of herpetofaunal communities on upland streams and beaver-impounded streams in the Upper Piedmont of South Carolina. American Midland Naturalist 145:54-65.

Orr, J.M. 2006. Microhabitat use by the Eastern Worm Snake, Carphophis amoenus. Herpetological Bulletin 97:29-35.

Pauley, T.K. 1973. The Status of the Genus Carphophis in Ohio and West Virginia. Proceedings of the West Virginia Academy of Science 45:64-70.

Rossi, J.V. and R. Rossi. 1993. Earthworms: A balanced diet for small snakes? Herpetological Review 24:56. 
Uhler, F.M., C. Cottam, and T.E. Clarke. 1939. Food of snakes of the George Washington National Forest, Virginia. Transactions of the 4 th North American Wildlife Conference 1939:605-622.

Vitt, L.J. and J.P. Caldwell. 2009. Herpetology. An Introductory Biology of Amphibians and Reptiles. 3rd ed. Academic Press, Burlington, Massachusetts.

Willson, J.D. and M.E. Dorcas. 2004. Aspects of the ecology of small fossorial snakes in the Western Piedmont of North Carolina. Southeastern Naturalist 3:1-12.
Willson, J.D., C.T. Winne, M.A. Pilgrim, C.S. Romanek, and J.W. Gibbons. 2010. Seasonal variation in terrestrial resource subsidies influences trophic niche width and overlap in two aquatic species: A stable isotope approach. Oikos 119:1161-1171.

Wright, A.H. and A.A. Wright. 1957. Handbook of Snakes of the United States and Canada. Vols. 1 and 2. Comstock Publishing Associates, Ithaca, New York. 